\title{
Article
}

\section{Waiting for a career epiphany - a barrier to decision-making?}

\author{
Houston, Kathleen and Cunningham, E.A
}

Available at https://clok.uclan.ac.uk/23473/

Houston, Kathleen orcid iconORCID: 0000-0001-7194-9588 and Cunningham, E.A (2018) Waiting for a career epiphany - a barrier to decision-making? Journal of the National Institute for Career Education and Counselling, 40 . pp. 25-32.

It is advisable to refer to the publisher's version if you intend to cite from the work. $10.20856 /$ jnicec4005

For more information about UCLan's research in this area go to

http://www.uclan.ac.uk/researchgroups/ and search for < name of research Group>.

For information about Research generally at UCLan please go to http://www.uclan.ac.uk/research/

All outputs in CLoK are protected by Intellectual Property Rights law, including Copyright law. Copyright, IPR and Moral Rights for the works on this site are retained by the individual authors and/or other copyright owners. Terms and conditions for use of this material are defined in the policies page.

\section{CLoK}

Central Lancashire online Knowledge www.clok.uclan.ac.uk

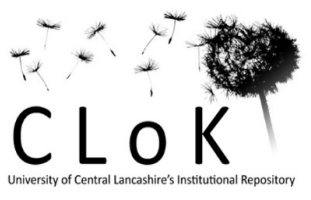




\section{Waiting for a career epiphany - a barrier to career decision-making?}

\section{Kathleen Houston and Eileen Cunningham}

\section{The}

desire for a career epiphany, a sudden realisation of a future career, can often feature as an unspoken wish in career conversations with students and graduates. This yearning for certainty causes indecisiveness, a fear of making the wrong decision or a 'not yet' conclusion.

In this qualitative research study, students and graduates confirmed themes of meta-indecision, a decision to not make a decision. Advice from graduates, careers advisers and employability academics challenged the need for absolute certainty as a prerequisite for first career decisions. This article argues that students and graduates can break through analysis paralysis and shape 'good enough' career plans.

- Key words: career guidance, decision-making, analysis paralysis, decision heuristics.

\section{Introduction}

'What are your future plans? What are you going to do after graduation?' These are the questions I am getting asked and trying to avoid in almost every conversation with an older person. I would answer those questions immediately, if only I knew the answer. The problem is - I am lost. I have a feeling of what I would like from my future, but I am just afraid of choosing the wrong pathway as I am not sure what really would make me happy.

- Justina, third year undergraduate student

Career decision-making is the focus of many a career guidance conversation in higher education. Career guidance professionals and tutors engage in lengthy and uneasy interactions with some students, undergraduate and postgraduate, who find the decision about the first study to work transition (the first job role after graduation) disquieting. This disquiet, typified by the above quote and characterised by variations of angst, uncertainty or procrastination, may be a feature of a normal life transition or a symptom of unwillingness to be a 'career decider'.

This quest for certainty can pose a challenge, not only for individuals but also for university careers services under pressure to demonstrate 'employability' by focusing on career planning and the all-important first destination (Christie 20I7). Graduates may also feel pressure from peers and family to settle into a career quickly (YouGov 2017). A fast-changing economic and political environment and the rise in levels of student debt can influence the decision-making landscape, where security and certainty are the perceived desirable endpoints of the university experience.

In the experience of the researchers (as career guidance professionals and employability lecturers) it seems that some students and graduates are stuck, waiting for a career epiphany, a 'knowing moment', which precedes a definitive career decision. A desire to help those in this predicament is the motivation for this investigation.

\section{Some key concepts in career thinking}

The designation 'career epiphany' is a term that seems to resonate with many people and features in Twitter key word searches. The concept of an epiphany with its religious connotation suggests a knowing and a showing, a sudden change of perception that is life changing. It may relate to the desire for a 'lightbulb' or 'eureka' moment of certainty with regard to a career decision - a moment that may, or may not arrive. 
The term 'career decider' is introduced here as a shorthand description for a student or graduate at the point of entry to the graduate job market (including first job, portfolio or self-employment roles), faced with a decisional tipping point.

'Career thinking' is more specific than theories of occupational choice, which attempt to explain how people choose a career. 'Career thinking' as a term within this research is proposed as a way of focusing on the decisional balances and heuristics that support effective and timely career decisions.

\section{Background and literature regarding career decidedness}

The subject of career decisions has been a key area of research within career studies. The broader context of career learning and occupational choice theories such as the DOTS model (Law and Watts 1997, 1996), planned happenstance (Mitchell 2003), and the focus on career decision-making within career guidance (Bimrose and Barnes 2007) are valuable entry points to the subject of career decisions. Decision-making styles such as 'rational, intuitive or dependent' (Harren 1979) or 'aspirational, evaluative, strategic and opportunist' (Bimrose and Barnes 2007) also offer useful paradigms for understanding patterns and strategies. However, the precise tipping point at which career decisions are made and how best to facilitate this is still often unclear.

Importantly, being a 'career decider' relates to the commitment, clarity or certainty with regard to career direction, signifying the decision point, not just the process of arriving at a decision (Restubog, Fiorentino and Garcia 2010; Fearon, Nachmias, McLaughlin and Jackson 2016,Artess 2018). This does not imply a once and for all decision but rather a willingness to make rather than defer decisions. This is congruent with the 'life design' model (Savickas 2009), whereby people continually construct their own careers. Career-decidedness may be considered a desirable attribute of self-direction for graduates within the protean, boundary-less career orientation (Hall 2004; Arnold 2016) with graduate recruiters favouring those who have demonstrated focus through specific work experience and internships (High Fliers 2017).
In trying to understand decision-making (or the lack thereof) social cognition theory offers us some useful insights. Examples include decision biases (Kahneman $20 \mathrm{II}$ ), overthinking, 'analysis paralysis' (Kane 20I5), 'choosing not to choose' (Sunstein 20I5) and maximising/satisficing preferences (Simon 1965 in Kane 2015). 'Maximising' is when someone seeks to know everything prior to making a decision and 'satisficing' means deciding to find out just enough to reach a decision point. As Schwartz (2004:79) maintains: 'the best people can do, all things considered, is to satisfice'.

An interesting alternative is the concept of the 'cognitive miser' (Fiske and Taylor 1984). It describes a mind state of decisional fatigue, which prevents a person from thinking. In practice decision-making may be characterised by simple heuristics (quick short cuts that help a person make a decision in the midst of uncertainty), or by anchoring heuristics, where someone is overly biased towards one piece of information. Festinger's (1957) notion of 'cognitive dissonance' suggests that holding contradictory thoughts or beliefs (e.g. internal expectations of life and information about the external reality) causes stress and mental discomfort until it is resolved. Each of these explanations resonated with researchers' experience of career discussions with students and graduates.

\section{The research}

Intrigued by this concept of a 'career epiphany, the researchers wondered whether a yearning for a career epiphany might act as a block to balanced and purposeful career decision thinking. This research explores the experiences of students, graduates and career guidance professionals engaging in these important first career transitions. The purpose and value of the research is to open up debate about how best to support career deciders and careers professionals in navigating this life transition and to identify practical advice and strategies.

\section{Methods}

This is an initial scoping exercise based on a qualitative, interpretative practitioner enquiry approach. A broadly phenomenological approach was chosen (Van Manen 2014) as being appropriate to the topic and the experiences of the researchers. Phenomenological 
research seeks to illuminate and understand lived experience and is concerned with a 'focus on peoples' perceptions of the world in which they live and what it means to them' (Langdridge 2007: 4).

A sampling of undergraduate and postgraduate students and graduates provided data for some initial judgments. Survey activity (36 survey forms returned by a mix of postgraduate doctoral researchers and undergraduate students) and individual short interviews (eight interviews) with graduates, using pre-determined questions (see Figure 2) resulted in a reasonable data set for qualitative analysis.

The selection of participants was purposive, drawn from those encountered by the researchers in their ancillary job roles as career coaches and employability lecturers. All participants were assured of anonymity and pseudonyms were used to denote individual comments. Informed consent was obtained.

As an addition to these traditional methods, social media channels were utilised to expand the scope. These involved a simplistic Doodle poll for students to complete, a Linkedln posting seeking the views of careers professionals and a series of tweets to generate a wider range of comments. Examples of the survey statements and the interview questions are found in figures $\mathrm{I}$ and 2 .

\section{The survey}

Students were asked to consider 18 statements which were representative of typical statements presented to careers advisers by students seeking career guidance. While they seem to be leading, this was justified as reasonable so that respondents could be definitive on a binary 'Agree' or 'Disagree' decision. There was an option to add their own statements.

\section{Figure 1 - Example statements}

- I am hoping I will work out what I want to do by the time I graduate.

- I'll decide when I have to.

- I want to suddenly realise what is right for me.

\section{The interviews}

The interview questions were formulated to explore the lived experiences of students and graduates, their cognitive and emotional responses, how they see themselves, the world and the future.

\section{Figure 2 - Interview questions}

What does 'career' mean to you?

- What don't you want career-wise?

- How would you know that a career or job role was right for you?

- What amount of certainty do you need before you would make a career choice decision?

- What decision-making process do you favour?

- What would help you to make your first career move or decision?

\section{Preliminary findings}

\section{Decision paralysis and analysis paralysis}

Thematic analysis of responses allowed for a focus on the most frequent and strongest themes (Braun and Clarke 2006). The interviews and survey responses indicated a range of narrative threads, which suggested that students were not only choosing not to choose (Sunstein 2015) but deciding not to decide. For example, one graduate emphasised the fear of making a wrong decision as a decision barrier.

I have always taken career planning as a heavy decision which determines my lifestyle choices in future years. - Jackson, third year student

Deferring a decision indefinitely forestalls an imperfect decision. It was clear that some students demanded an impossible degree of certainty before they could decide to decide. Supplementary to this view, it became apparent that despite some awareness of the out datedness of the 'one life one career' model, students still viewed the first career choice after graduation as an abiding and perpetual influence on their whole life.

Career plans have been an area of conflict for me as the career I choose will likely influence the rest of my life. - Fred, third year student

A further theme, from survey responses particularly, suggested that some students favoured a 'maximising' 
approach (Simon 1956, quoted in Kane 2015; Schwartz 2002) examining every option before making a decision, thus inadvertently delaying the decision and potentially over-analysing every potential career role. This over-thinking approach sometimes resulted in an unintentional avoidance strategy. The maximiser or 'cognitive optimizer' (Brockman 2013:39) approach is related to the rational decision-making model that extols the value of thorough research, considering all information and seeking the 'optimal choice' (Brockman 2013:39).

While this seems sensible, Fiske (1993) suggests that thinking too hard tests our cognitive capacity and reduces our ability to make a decision, playing to a 'cognitive miser' tendency. Gigerenzer (200I) recommends 'smart heuristics', what Brockman (2013:40) refers to as 'fast and frugal decision-making', on the basis that there is often not enough information available to pick the optimal solution after rational weighing up.This smart decision-making works on the 'satisficing' construct (Simon 1956, quoted in Kane 2015) and may also rely on a more intuitive preference for making decisions (Greenbank 2017:276). Fiske (1993) warns against these 'cognitive shortcuts' while accepting that this is necessarily a kind of 'cognitive coping'.

Interestingly, a number of commentators argue that delaying or deferring a decision results in a kind of fixed hesitation mind-set that makes it likely no decision will be made (lbarra 2002; Sunstein 20I5). This also relates to the contemplation mode of Prochaska and DiClemente's spiral model of change (2000:49). In the contemplation phase of the cycle, an individual may be aware of a problem (a career decision problem) but have no commitment to taking any action about this. There seems to be a curious, self-deluding comfort in this contemplation mode if it is, in fact, not a precursor to action. Within this view, a career decider needs to be supported and encouraged to move into the preparation phase (of the model of change), where there is an intent to take action.

\section{Career epiphany}

There were two survey statements which received very strong agreement amongst students and graduates. Both supported the phenomena of waiting for a career epiphany. This notion of a career epiphany indicates a perceived expectation by some students and graduates that they will 'realise' suddenly what should be the 'right' career direction, often without much conscious effort.

Overwhelmingly, a majority agreed with the statement:

I want to suddenly realise what is best for me.

Similarly, a further consistency in 'agree' statements was:

l'd be much happier if I could make a career decision.

It is evident these students recognise the need for a decision point. If in fact these students are maximisers, it might suggest that having too many career ideas can be a kind of entrapment. Ibarra (2002) suggests that 'being stuck' is partly about the need to know everything before taking action; she recommends action as a precursor to knowing. Students could test out career ideas, rather than just thinking about them, as a way of understanding their own preferences more completely.

From initial conversations with careers professionals, this yearning for clarity presented itself frequently in career guidance interactions as a need to 'know', almost instinctively, what the best career choice should be. Further interviews with careers advisers confirmed that this expectation was common and frequently an obstacle to decision-making and clear career thinking.

\section{Values based decision-making}

Finally, a theme emerged around career decisionmaking, which suggested that many participants realised the importance of their values: I want to find a way to create a careerljob pattern that fits with my values and motivation.

This statement received the most agreement across the different cohorts and year groups. Personal values are a well-regarded predictor of career motivation (Gibbs and Griffin 2013; Rokeach 1973; Fearon et al 2016) that fit with the need for a self-directed decision-making approach. Greenbank (2017:276) discusses the influence of student values on decisionmaking, noting that 'students demonstrated a preference for making intuitive decisions based on informally absorbed information (rather than research) 
and a 'feel' for the right decision'. Additionally, there is a suggestion in this statement of a desire for a more fluid work pattern, one which fits with Savickas' (2009) 'life design' idea of career planning. This makes it even more relevant in terms of a values-driven approach.

\section{Career misery push and the lure of the dream job}

Interviews with graduates offered valuable insight into how career choices are activated and how selfdirected careers are shaped. It became evident that being in the wrong job (a first career choice) acted as a prompt towards a better second choice. This 'career misery push', a term that seemed to encapsulate a commonly expressed unhappiness caused by a career false start after graduation, was significant in driving motivation to seek a better career role and make a more effective decision.

Doing the wrong job acted as a catalyst and helped me know what I didn't want and helped me realise what I did want to do.

- Miles, graduate

If cognitive dissonance (Festinger 1957) is a drive for consistency in terms of what motivates an individual, then it is possible that career misery acts as an activator of massive dissonance, which in its turn causes enough disequilibrium to 'push' the person to take control and be a more active, purposeful career decider.

Other graduates claimed that developing an awareness of their own core values within a first role, drove them towards a better second career choice. This was particularly emphasised by Maria who believed she had achieved her 'dream job' in her first career role. She was surprised to realise that she wanted more fulfilment than this initial role offered. She consequently identified her criteria for a meaningful career life based on her own developed self-knowledge:

Hitting that point of realising what you want to do, surrounded by smart people...interested and engaged.

- Maria, graduate

As a result, Maria was able to seek out a work role in a proactive way, one that matched her values and strengths. This supports the idea of decisional balance
(Miller 2015) where the individual acknowledges and weighs up the criteria that matter most to them, in terms of a fulfilling career. Notably the recognition of a point, the tipping point, which prompts a realisation was evident in this graduate interview. Similarly, other graduate interviewees affirmed that self-knowing plus curiosity and proactivity were the characteristics they relied upon, to inform and support their own career decidedness.

\section{Implications for practice}

\section{Recommendations from graduates}

Graduates who had successfully navigated the early career rapids, the successful career deciders, shared their advice for effective career decision-making. They offered some extremely insightful suggestions.

'Look as much as you can' and 'Find out all the different things you can do - use this process as a good kind of procrastination' (Harriet), a version of the maximising approach.

Nathaniel suggests 'An hour with someone to discuss ideas, to gain confidence to follow own instincts and be given the tools to work it out for themselves'

Sofia recommends - 'Research, lots of research'.

Overall, the graduates commended thorough exploration of career paths driven by attention to personal values; an action orientation in terms of testing out job roles; and a willingness to see a first career decision as not binding in terms of future career plans.

\section{Recommendations from career professionals}

Career professionals recognised that the expectation of a career epiphany or sudden realisation was a common aspiration. The passivity characteristic of this enticingly aspirational state was agreed to be disadvantageous. They endorsed the view that many students are not ready to make a career decision, some being vague, in a panic or avoiding contact with career guidance professionals. Procrastination and delay in terms of career thinking were more common than any kind of certainty. 
Professionals supported the ideas that values-based activities can develop the required self-knowledge and that time needs to be allocated for practical research into career paths involving internships, work shadowing, networking and active 'prospecting' for career ideas. They believed it was important to challenge the idea of a 'forever career choice' or the concept of one perfect job for each person. One careers adviser, Agnethe, suggests 'values are the best indicator of career preference. Doing a values inventory raises awareness of what is needed for a career choice.'

\section{Conclusions}

There is a timeliness to the topic of career decidedness in higher education. The new 'Longitudinal Education Outcomes' (LEO) to be introduced in 2018 recognises that postgraduate career transitions are longer and more complex than in the past (HESA 2017). The Career Decidedness Survey (Figure 3) designed by The Careers Group, University of London is being used as part of registration in many universities. The survey assesses where students are on the Decide/Plan/Compete/Sorted spectrum (Gilworth
2016) and raises the profile of career decidedness as an important component of employability learning. Interestingly, a consortium of 16 HE careers services have recently found that over $40 \%$ of students entering their final year are still 'deciding' (Winter 2018).

This research has identified and clarified some useful concepts (career thinking, career decider, career misery push and career epiphany) which may resonate with practitioners, helping them to identify the pitfalls of procrastination and develop practical strategies to tackle it. Based on this investigation, the notion of a career epiphany aspiration was supported as a phenomenon. While an appealing concept, it would seem that waiting for an epiphany could delay career decisions. Recognising this decisional paralysis and its disadvantages can spark an action-oriented process of exploration.

Career professionals can play a part in encouraging a multi-faceted approach to deciding that combines research with rational and intuitive activity allowing for a 'satisficing' decision. Helping students and graduates to understand decisional balance approaches can encourage balanced career thinking and galvanise purposeful action. Introducing tools such as values

Figure 3 - Career Decidedness survey (The Careers Group, University of London 2016)

\section{Career Decidedness (CD)}

\section{Readiness to engage with career management - Decide, Plan, Compete}

Please select the statement which best represents your current careers position:

I am not ready to start thinking about my career yet (Decide)

I have no career ideas yet but want to start thinking (Decide)

I have some ideas about my career \& am ready to start planning (Decide)

- I have a career in mind \& intend to gain relevant work experience (Plan)

O I know what I want to do but not sure how to get there (Plan)

- I want to spend a year gaining experience (Plan)

O I am ready to apply for graduate level / professional opportunities (Complete)

O I am ready to apply for further study (Complete)

O I have been applying for opportunities \& have not been successful (Complete)

I have a job, further study or my own business plan confirmed (Other) 
tests, career anchors (Schein 1990), appreciative inquiry (Cooperrider and Whitney 2005) and Seligman's signature strengths tests (2017) can enhance self- and career-knowing that can lead to purposeful testing out of career paths. Encouraging such a proactive career thinking approach has the potential to trigger career realisations that lead to pragmatic decisions.

Identifying the career misery push in graduates allows careers professionals to offer more than sad cautionary tales of underemployed graduates in their guidance; it demonstrates that career knowing or epiphanies can emerge out of the experience of working, even in a less than perfect job. Graduates who yearn for an epiphany can create their own epiphany proactively, rather than wait for it to happen, a strategy or mind-set supported by the planned happenstance approach (Mitchell 2003).

Encouraging students and graduates to be 'choosers' not 'delayers' must be the aim for career professionals. This is in no way intended to encourage a fixed career direction. The career decider must be encouraged to see this as just the first of many decisions for the selfdirected and value driven protean or boundary-less career, appropriate for the 21 st century job market (Hall 2004;Arnold 2016). It is about helping them to see themselves as the hero in their own career story, engaging in it as a process rather than as a single irreversible event.

Helping people understand what matters most for their career life is a worthy pursuit.Valuable careers guidance can be found in the novel 'The Secret Life of Bees' by Sue Monk Kidd (200I): 'The whole problem with people is...they know what matters, but they don't choose it...the hardest thing on earth is choosing what matters'. (p. 147)

\section{References}

Arnold, J. (20I I) Career Concepts in the 2 Ist Century https://thepsychologist.bps.org.uk/volume-24/edition-2/ career-concepts-2Ist-century (accessed 16/I I/2017)
Artess, J. (2018) Learning to be employable, in Christie, F., and Burke, C., eds. (forthcoming). Graduate Careers in Context: Research, Policy and Practice, Routledge

Bimrose, J. \& Barnes, S-A. (2007) Navigating the Labour Market: Career Decision Making and the Role of Guidance, Warwick: IER.

Braun, V. \& Clarke,V. (2006) Using thematic analysis in psychology. Qualitative Research in Psychology, 3 (2). pp. 77-101.

Brockman, J. (Ed) (20/3) Thinking, New York: Harper Collins.

Christie, F. (2017) The reporting of university league table employability rankings: a critical review. Journal of Education and Work, 30(4), 403-4I8, http://dx.doi:10.1080/13639080.2016.122482I

Cooperrider, D. \& Whitney, D. (2005) Appreciative Inquiry, San Francisco: Berrett-Koehler Publishing Inc.

Fearon, C., Nachmias, S., McLaughlin, H., \& Jackson, $S$ (2016) Personal Values, social capital, and higher education student career decidedness: a new 'protean'informed model, Routledge: Studies in Higher Education, http://dx.doi.org//0.1080/03075079.2016.116278I

Festinger, L. (1957) A Theory of Cognitive Dissonance, Stanford: Stanford University Press.

Fiske, S. (1993) Researching the Presidency Pittsburgh: University of Pittsburgh Press.

Gibbs, K.D. \& Griffin, KA (20I3) What do I want to do with my PhD? The Roles of Personal Values and Structural Dynamics in Shaping the Career interests of Recent Biomedical Science PhD Graduates, CVE - Life Sciences Education I2(4); 7 I I-723.

Gigerenzer, G. \& Todd, P.M. (200I) Simple Heuristics that make us smart, New York: Oxford University Press.

Gilworth, B. (December 20I6) Presentation on Careers, Employability and Learning Gain, https://www.slideshare. net/LuciaGarcia7I/bob-gilworth-64052 I49 (accessed I August 2017).

Greenbank, P. (20I7) Encouraging Students to Develop their Employability, in Tomlinson, M, \& Holmes, L

(eds) Graduate Employability in Context Ch 13, 273-289, London: Palgrave Macmillan. 
Hall, D.T. (2004) The Protean Career:A quarter century journey' Journal of Vocational Behaviour 65: I (August 2004)

Harren,V.A. (1979) A model of career decision-making for college students, Journal of Vocational Behaviour, 14, II9-133.

HESA (2017) (accessed 9/II/I7) https://www.hesa. ac.uk/innovation/records/reviews/newdlhe/model

High Fliers (2017) The Graduate Market in 2017 (accessed 18/I//8) https://www.highfliers.co.uk/ download/2017/graduate_market/GMReport 17.pdf

Ibarra, $\mathrm{H}$ (2002) How to stay stuck in the wrong career Harvard Business Review, https://hbr.org/2002//2/ how-to-stay-stuck-in-the-wrong-career (accessed I5/II/2017).

Kahneman, D (20I I) Thinking Fast and Slow, New York: FSG Books

Kane, B. (2015) The Science of Analysis Paralysis, http:// blog.todoist.com/2015/07/08/analysis-paralysis-andyour-productivity Accessed 19 May 2016

Langdridge, D. (2007) Phenomenological Psychology:

Theory, Research \& Method, Harlow: Pearson

Law, B. \& Watts, A.G. (1977) Schools, Careers and Community, London: Church Information Office.

Law, B. (1996) A career-learning theory, in Watts, A.G., Law, B., Killeen, J., Kidd, J.M. \& Hawthorn, R. Rethinking Careers Education and Guidance:Theory, Policy and Practice, London: Routledge, 210-232.

Miller,W.R. (2015) Motivational interviewing and Decisional Balance, Behaviour and Cognitive Psychotherapy 43, 129-I4I.

Mitchell, K. (2003) The Unplanned Career, San Francisco: Chronicle Books.

Monk Kidd, S. (200I) The Secret Life of Bees, London: Headline Book Publishing.

Prochaska, J.O., Norcross, J.C., \& DiClemente, C.C. (2000) Changing for Good, New York: Harper Collins.

Restubog, S.L.D., Fiorentino, A.R., \& Garcia, P.R.J.M. (2010) The Mediating Roles of Career Self-Efficacy and Career Decidedness in the Relationship between Contextual Support and Persistence, Journal of Vocational Behaviour 77(2): I86-95.

Rokeach, M.J., (1973) The Nature of Human Values, New York: Free Press.

Savickas, M. (2009) Life Designing:A paradigm for career construction in the 2 I st century, Journal of Vocational Behaviour, 75, 239-250.

Schein, E. (1990) Career Anchors - discovering your real values, San Francisco: Jossey Pfeiffer.

Schwartz, B. (2004) The Paradox of Choice New York: Harper Collins.

Seligman, M. (2017) Authentic Happiness https://www. authentichappiness.sas.upenn.edu/ (accessed I August 2017).

Sunstein, C.R. (20I5) Choosing not to Choose, New York: Oxford University Press

Van Manen, M. (2014) Phenomenology of Practice, New York: Routledge

Winter, D. (20/8) The Rise of the Practitioner Researcher in Christie, F., and Burke, C., eds. (forthcoming). Graduate Careers in Context: Research, Policy and Practice, Routledge

YouGov (2017) Eight in ten students feel pressure to get a job within 6 months of graduating https://yougov.co.uk/news/2017/07/1//eight-tenstudents-feel-pressure-get-job-within-6-/ (Accessed 9/11/17)

\section{For correspondence}

Kathleen Houston

Senior Lecturer in Employability and Enterprise

KHouston@uclan.ac.uk

Eileen Cunningham

Lecturer in Social Policy, Careers Adviser and Chartered Occupational Psychologist

e.a.cunningham2@salford.ac.uk 